\title{
THE EFFECT OF AGRICULTURAL AND ENERGY PRICES ON BIOMASS PRODUCTION: THE CASE OF TRITICALE IN THE OECD AREA
}

\author{
Caterina de LUCIA \\ University of Foggia, Department of Economics \\ 71121 Foggia, Italy \\ E-mail: caterina.delucia@gmail.com \\ Francesco CONTO \\ University of Foggia, Department of Economics \\ 71121 Foggia, Italy \\ E-mail: francesco.conto@unifg.it \\ Pasquale PAZIENZA \\ University of Foggia, Department of Economics \\ 71121 Foggia, Italy \\ E-mail: pasquale.pazienza@unifg.it \\ Vincenzo VECCHIONE \\ University of Foggia, Department of Economics \\ 71121 Foggia, Italy \\ E-mail: vincenzo.vecchione@unifg.it
}

doi:10.13165/IE-13-7-4-03

\begin{abstract}
Through the use of the econometric technique of panel data, this work mainly investigates the relationships between agricultural and energy prices and the land use for triticale, which is nowadays seen as one of the most important biomass crops. This is done with the aim of assessing the land use implications potentially associated to the existence of policies implementing forms of incentive for renewable energy production. The analysis is developed while considering 22 selected OECD countries observed over a period of 17 years, between 1995 and 2011. The analysis results suggest that the estimated functional shape of the land use for triticale mainly depends upon variations in the yield, producer and electricity prices. The policy implications, which might be derived from these findings, highlight how farmers would not be willing to substantially increase the area devoted to triticale unless the adoption of some forms of economic incentives to enhance bio-energy production is taken into consideration.
\end{abstract}

JEL classification: Q15, Q20, P28.

Keywords: biomass production, land use, panel data, agriculture and energy markets.

Reikšminiai žodžiai: biomasès gamyba, žemès naudojimas, paneliniai duomenys, žemès ūkis, energijos rinkos. 


\section{Introduction}

According to FAO (1996: 43), food security is a condition that "exists when all people, at all times, have physical and economic access to sufficient, safe and nutritious food to meet their dietary needs and food preferences for an active and healthy life". If the economic aspect is referred to, it is possible to observe how, over the last years, food security has been endangered due to the worldwide increase of the food commodities price, which reached its peak in 2006 and 2007. In fact, during the first half of 2008, the real price index of food commodities increased by $64 \%$ compared to the previous decade (FAO, 2008). This would prove the existence of failures in agricultural markets. As a result, the need of analysing their driving forces to identify and implement adequate forms of policy interventions - based on the evaluation of social, economic and environmental effects - is particularly felt to orient emergency interventions and, overall, investment decisions (OECD-FAO, 2006).

Within this context of argument, the impact of bio-energy production on agricultural commodities prices is the subject of a vivid scientific debate. Its potentially positive impact on energy safety, mitigation of climate change, natural resources use and the development of the agricultural sector is very often recognized and highlighted (IEA, 2013; DEFRA, 2008). However, it is also argued that over the next decade the use of bio-energy from bio-fuels will play a minimal role in compensating the broadly desired reduction of fossil fuel use. Instead, major effects are expected in relation to a higher probability of compromising food safety levels. Even though bio-energy production is more focused on the use of some specific agricultural commodities, which can be considered of minor importance for human feeding (e.g. sugar, maize, oil seeds and palm oil), the increase of their prices together with the increase of the price of food and other agricultural resources would be consequential (FAO, 2008). Hence, this would result in a serious threat to food safety for most low income farmers in the short run. In the long run, however, food price increases would only partially be affected by bio-energy production (FAO, 2009). Other factors must also be considered, such as agricultural production shortfalls caused by climatic conditions in major export countries, low levels of world cereal stock, fuel cost increases, changes in the structure of demand associated with increasing world population and urbanization, financial market operations and exchange rate fluctuations (De Lucia \& Datta, 2012; FAO, 2009).

The International Energy Agency (2011) argues that bio-energy productions have the potential to affect land use change both directly and indirectly. Although only about $1 \%$ of world agricultural land is used for bio-energy crops, it can be argued that the effects on land use may be irrelevant (IEA, 2011). However, an efficient emission reduction policy should take into account all possible effects on land conversion. Generally speaking, direct land use effects arising from biomass crops imply the change of production modes from food to energy commodity (e.g. changes in crop rotations, forest management or pasture lands). Indirect land use changes, on the other hand, consider effects taking place elsewhere due to the implementation of bio-energy crop productions (e.g. displacement effects) with possible implications to changing natural ecosystems (De Lucia, 2011; Ernst \& Young, 2011; IEA, 2011). Should this be the case, the quantification 
of all possible damages in terms of biodiversity loss or indirect emissions would be difficult to estimate.

Furthermore, the demand of world bio-energy compared to global world energy demand is low. This appears to be relevant to current levels of agricultural production and a significant aspect to be considered for socio-economic and environmental implications. From the environmental point of view, greenhouse gases emission reductions are among the main policy justifications to support bio-energy production. With regard to this, the current literature argues how these reduction scenarios vary according to food product mix in agriculture, emissions of nitrous oxide in soil and the changes occurring in $\mathrm{CO}_{2}$ concentrations due to changes in agricultural land-use (FAO, 2009; Fargione et al., 2008; Naylor et al., 2007; Righelato \& Spracklen, 2007). Due to the reasons recalled insofar, the importance of avoiding mistakes in the identification and the implementation of agricultural income and energy policies in the short as well as in the long run appears in all its evidence. To this purpose, the understanding of the actual development scenarios is of relevant importance.

The purpose of this paper is to analyse the relationship existing between agricultural, energy prices and the land use for triticale that is one of the most important crops for biomass production. As a result, it is organized as follows. The first section is devoted to highlight in more detail some considerations on the trade-off between the use of agricultural land for food and/or energy production purposes. The second section puts into evidence the case of triticale as a crop used to satisfy both food and energy demand and analyses its trends of production over the last 36 years or so. In the further section, after a description of the data used, the empirical analysis based on the econometric technique of panel data is developed to infer on the interdependencies between land use for triticale and other economic variables (especially those related to agricultural and energy market prices). The next section focuses on the comment of the achieved results and some policy considerations made in the light of the obtained results. Some concluding remarks are finally reported in the last section.

\section{Land use and bio-energy production: issues and considerations}

Over the last decades, the international community has paid considerable and increasing attention - in both scientific and political terms - to the implications of agricultural land use for energy biomass production. A number of reasons can explain this growing interest. Very briefly, it can be firstly said that biomass can be used to replace fossil fuels and create energy services, such as electricity and heating (IPCC, 2000). This can generate benefits in terms of greenhouse gas (GHG) emission reductions (IEA, 2012). However, this "happy view" is counterbalanced by the general concern that the expansion of crops dedicated to energy production can harm the possibility that agriculture can keep producing food at accessible prices. As it is often referred, the fact that agricultural land can be oriented to bio-energy production poses some serious problems in terms of identifying a right balance between food and energy production purposes (IEA, 2013; Ernst \& Young, 2011). 
Global use of edible oils, for example, grew faster than their production capacity between 2004 and 2007. This generated an excess of demand worldwide. As a result, the price of such oils and food increased, in so doing, it generated inflation mechanisms with negative repercussions to developing countries (FAO, 2009). Furthermore, the increase of the world population growth rate implies increasing demand for food and bio-energy making the problem of food and fuel shortages even worse and leads to other significant problems, such as starvation in developing countries. With nearly $60 \%$ of humans in the world malnourished, the need for grains and other basic food crops continues to be critical (De Lucia \& Datta, 2012). In fact, the estimated demand for food is expected to double over the next 50 years (Fedoroff \& Cohen, 1999), causing an increased competition of agricultural land needed for food versus energy production.

With regard to this, some studies argue that biomass production will play a substantial role in agriculture in the future, especially if it is considered in relation to the use of marginal land (e.g. IEA, 2010). The current literature shows a number of future scenarios of land availability worldwide. For example, in another study conducted, the International Energy Agency (2006) identifies 1.7 Giga-hectars (Gha) of unfertile land available worldwide and 4 Gha of agricultural land. This seems promising if compared to the scenario designed by Hoogwijk et al. (2003), where no agricultural land would be available by 2050 . On the basis of these considerations, it is apparent how an adequate planning activity should consider unfertile land for the cultivation of bio-energy. Another factor to be considered for the development of biomass is the use of wasteland or wastewater to grow potential feedstock. In addition, forest and crop residues would contribute to the expected increase of bio-energy demand (VTT, 2007). In the European Union, a study carried out by Smeets et al. (2007) estimated that under an optimistic scenario a surplus of 129-592 Mega hectares (Mha) of marginal land would have an impact of potential energy production from biomass between 100 Exajoule (EJ) and 303 EJ.

\section{The triticale as a crop for energy production}

The present study focuses on the case of triticale. This is a specific crop, which can be used for satisfying both food and energy demand. With regard to the first aspect, the triticale has a better amino-acid composition than other cereals (i.e. corn) and, therefore, it has a major potential to be grown as an energy crop rather than corn, wheat and/or sorghum (Barnett et al., 2002). In relation to the second aspect, it is considered as being an energy crop for heating and electricity purposes. The triticale is a hybrid cereal obtained from mixing wheat and rye. It is generally characterized by a relevant productivity even when cultivated in marginal lands. As a result, the triticale has the potential to be used as a feedstock for biomass purposes. Since 1985, the global market for the triticale has considerably expanded (Figure 1), as has the yield (Figure 2), despite the abnormally cold winter of 1983 in the US and Canada, which negatively affected the yield (Barnett et al., 2002). 
Figure 1. World triticale production (in .000 t.) and area harvested (in .000 ha.) between 1975 and 2011

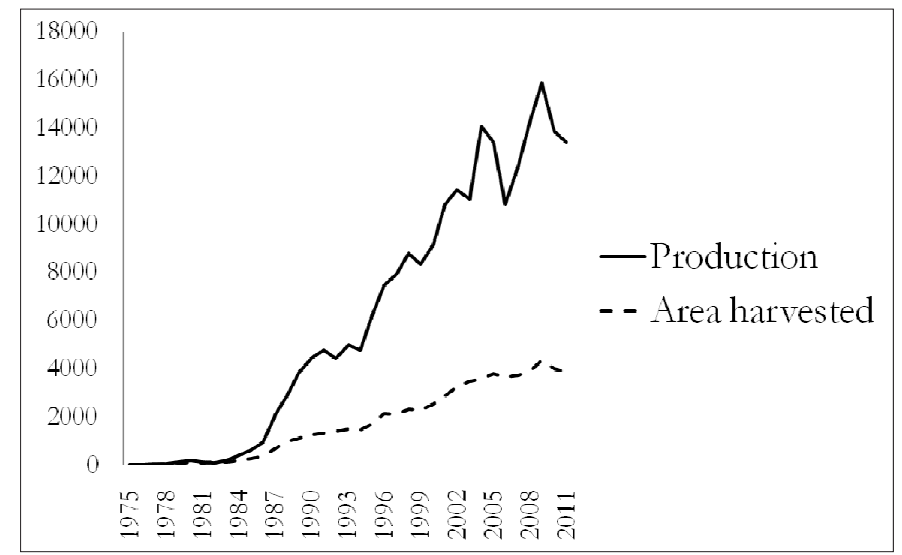

Source: own elaboration on FAOSTAT data

Figure 2. Triticale yield (in tonnes/ha.) between 1975 and 2011

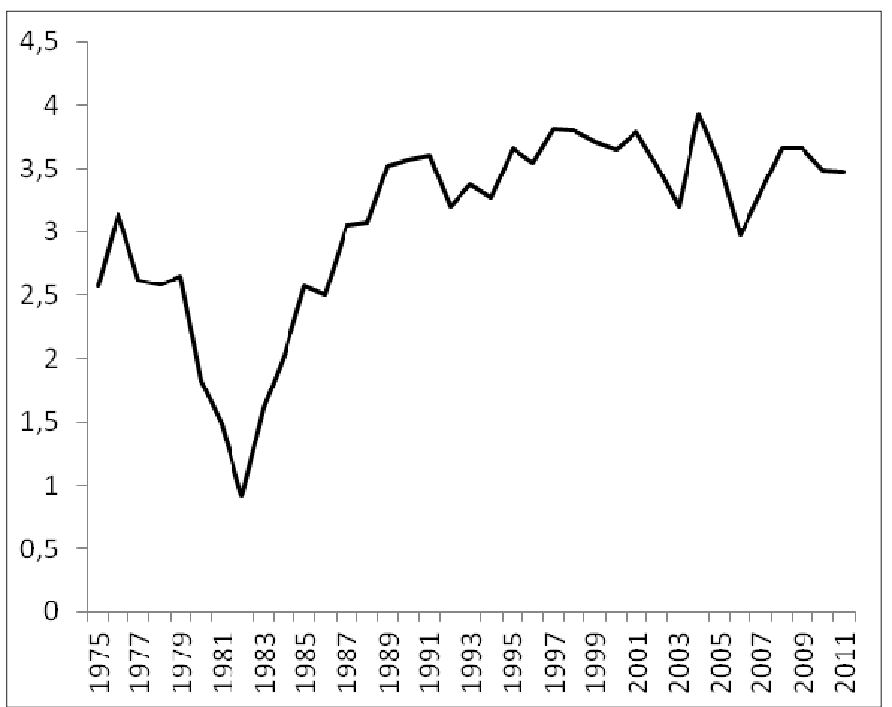

Source: own elaboration on FAOSTAT data

Nowadays, the triticale has several development potentials in the bio-refinery industry and shows particular advantages, which make it be considered as a sustainable 
crop. First, the triticale can be grown on marginal lands; it requires a very minimal use of water during cultivation and is characterized by the complete absence of $\mathrm{CO}_{2}$ release during "extraction" processes. Second, the triticale is very competitive. It generates a notable profitability for farmers, which is accompanied by a high potential of business development and increasing employment in rural areas. Third, its chemical processes through fermentation and fractionation techniques would contribute to obtain green biomass and other potential developments in the bio-plastic and polymer industries.

\section{Data and methods for the empirical analysis}

The empirical analysis aims mainly at inferring on the possible relationships between land use for the triticale and the prices observed in the agricultural market, as well as those in the energy market. To this end, as it will be described later in this section, the authors worked on a dataset containing both spatial and temporal dimensions. The spatial dimension pertains to a set of cross-sectional units of observation, whereas the temporal dimension can be characterised by various temporal sources, such as years, months or daily observations (Yaffe, 2003). More specifically, the data refer to 22 OECD countries observed between 1995 and 2011 and are investigated through the employment of the panel data technique, since it endows regression analysis with both spatial and temporal dimensions. The generic functional form subject of the investigation can be represented as follows:

$$
\begin{aligned}
& \text { AREABIO }_{\mathrm{it}}=\alpha_{\mathrm{i}}+\beta_{1} \text { YIELD }_{\mathrm{it}}+\beta_{2} \text { PPRICEX }_{\mathrm{it}}+\beta_{3} \mathrm{QTPOP}_{\mathrm{it}}+\beta_{4} \text { DPOP }_{\mathrm{it}}+ \\
& +\beta_{5} \text { PELEC }_{\mathrm{it}}+\beta_{6} \mathrm{D}_{-} \mathrm{EU}_{\mathrm{it}}+\beta_{7} \mathrm{D}_{-} \text {FEEDIN }_{\mathrm{it}}+\varepsilon_{\mathrm{it}}
\end{aligned}
$$

More specifically, the land used for the triticale (AREABIO) is the dependent variable and is obtained from the computations on FAO data. This variable is here considered as the percentage obtained from the ratio between the triticale harvested area and the total agricultural area. Among the dependent variables, the authors of this paper considered the following: the triticale productivity (YIELD) expressed in tonnes/ ha.; producer price index for triticale (PPRICEX) (the average price 2004-2006 = 100); the per-capita quantity of triticale in tonnes (QTPOP); the country population density (DPOP), given by the ratio between the country area and the population). The electricity price (PELEC) in USD/MWh from IEA Energy Statistics is also considered. Furthermore, two dummy variables have been added to the model: D_EU, which takes the value of 1 for those countries belonging to the European Union, and D_FEEDIN, which takes the value of 1 when some forms of incentive for renewable energy production exist. Finally, $\varepsilon_{\mathrm{it}}$ is the error term. Having said this, it is now worth noting the predictions that the authors associated to the coefficients of the variables considered in the model. For the variables YIELD, PPRICEX and PELEC, the higher the variations in these variables, the larger the area for the triticale required for biomass purposes. Similarly, the presence of feed-in tariffs would positively affect the area devoted to the triticale. The authors also expected a positive relationship between the EU dummy 
(D_EU) and AREABIO. This is because the largest worldwide producers of the triticale are Poland, France and Germany. Finally, for the DPOP, the authors expected the existence of either a positive or negative relationship with the AREABIO. This scenario was based on the idea that the higher population density, the higher the land use required that would result to satisfy energy needs. On the other hand, high population density would also indicate that land use is also needed to satisfy food requirements. Table 1 below schematically synthesizes the description of the variables used in the model and gives indications about the data-source. Furthermore, it highlights the predictions of the coefficients sign.

Table 1. Variable descriptions, variable sources and predicted coefficient signs

\begin{tabular}{|c|c|c|c|}
\hline Variable & Description & Data source & Predicted coefficient sign \\
\hline AREABIO & $\begin{array}{l}\text { Ratio between the triticale } \\
\text { harvested area and the total } \\
\text { agricultural area }\end{array}$ & FAOSTAT & Dependent variable \\
\hline YIELD & Yield for the triticale in tonnes/ha. & FAOSTAT & $\frac{\partial \text { AREABIO }_{\text {it }}}{\partial \text { YIELD }_{\text {it }}}>0$ \\
\hline PPRICEX & $\begin{array}{l}\text { Triticale producer price index } \\
\text { (average price } 2004-2006=100 \text { ) }\end{array}$ & FAOSTAT & $\frac{\partial \text { AREABIO }_{\text {it }}}{\partial \text { PPRICEX }_{\text {it }}}>0$ \\
\hline QTPOP & $\begin{array}{l}\text { Per-capita quantity of the triticale } \\
\text { (in tonnes) }\end{array}$ & FAOSTAT & $\frac{\partial \text { AREABIO }_{\text {it }}}{\partial \text { QTPOP }_{\text {it }}}>0$ \\
\hline DPOP & $\begin{array}{l}\text { Population density } \\
\text { (= population/country area in ha.) }\end{array}$ & FAOSTAT & $\begin{array}{c}\frac{\partial \text { AREABIO }_{\text {it }}}{\partial \text { DPOP }_{\text {it }}}>0 \\
\text { or } \\
\frac{\partial \text { AREABIO }_{\text {it }}}{\partial \text { DPOP }_{\text {it }}}<0\end{array}$ \\
\hline PELEC & $\begin{array}{l}\text { Electricity price for households } \\
\text { (in USD/MWh) }\end{array}$ & $\begin{array}{l}\text { IEA Energy } \\
\text { Statistics }\end{array}$ & $\frac{\partial \text { AREABIO }_{\text {it }}}{\partial \text { PELEC }_{\text {it }}}>0$ \\
\hline D_EU & $\begin{array}{l}\text { Dummy variable: } 1 \text { if country } \\
\text { belongs to the EU, } 0 \text { if otherwise }\end{array}$ & - & $\frac{\partial \mathrm{AREABIO}_{\mathrm{it}}}{\partial{\mathrm{D} \_U_{i t}}_{\text {it }}}>0$ \\
\hline D_FEEDIN & $\begin{array}{l}\text { Dummy variable: } 1 \text { if a feed } \\
\text { in tariff for renewable energy } \\
\text { is present in a given year and } \\
\text { country; } 0 \text { if otherwise }\end{array}$ & $\begin{array}{c}\text { EU energy } \\
\text { portal and } \\
\text { IEA energy } \\
\text { statistics } \\
\end{array}$ & $\frac{\partial \text { AREABIO }_{i t}}{\partial \text { D_FEEDIN }_{\text {it }}}>0$ \\
\hline
\end{tabular}




\section{The analysis results}

Among the various data transformations and functional forms estimates that have been tried for the analysis, the log-log equation has provided the best result in terms of model's explicatory power and statistical significance of the variables. Below, Table 2 reports the OLS (Ordinary Least Squares), FE (Fixed Effects) and RE (Random Effects) results of the estimates.

Considering the results achieved from the BP Lagrangian multiplier and the Hausman tests, the authors chose the FE model, which result will be the subject of attention from now on. In fact, with more specific regard to the Hausman diagnostic used to test the validity of a RE model against a FE model, the authors observed that the null hypothesis - associated to the consistency of the RE model - can be rejected at 95\% Confidence Interval. In other words, the fixed effect model can be considered consistent (although inefficient) to the purpose of the present investigation (Greene, 1997; Johnston \& Di Nardo, 1997). The adoption of the FE model to explain the relationships subject of the investigation would mean that similarities in land use policy and planning would exist across countries and over the considered time. As already said, the estimation is put in logarithmic terms. As a consequence, the results of the correlations among the considered variables are read as percentage variations (elasticities).

Table 2. Model estimates with robust standard errors

\begin{tabular}{|c|c|c|c|}
\hline Variables & OLS & FE & RE \\
\hline YIELD & $\begin{array}{l}0.23^{\star} \\
(0.11)\end{array}$ & $\begin{array}{l}-0.83^{*} \\
(0.120)\end{array}$ & $\begin{array}{l}-.769^{\star} \\
(.125)\end{array}$ \\
\hline QTPOP & $\begin{array}{l}0.78^{\star} \\
(0.02)\end{array}$ & $\begin{array}{c}0.87^{\star} \\
(0.122)\end{array}$ & $\begin{array}{l}.860^{*} \\
(.120)\end{array}$ \\
\hline PELEC & $\begin{array}{c}0.37^{\star} \\
(0.07)\end{array}$ & $\begin{array}{l}0.13^{\star} \\
(0.04)\end{array}$ & $\begin{array}{l}.138^{*} \\
(3.07)\end{array}$ \\
\hline PPRICEX & $\begin{array}{c}-0.11 \\
(0.14) \\
\end{array}$ & $\begin{array}{l}0.11^{* *} \\
(0.06)\end{array}$ & $\begin{array}{l}.114^{* *} \\
(1.76) \\
\end{array}$ \\
\hline D_FEEDIN & $\begin{array}{c}0.09 \\
(0.15)\end{array}$ & $\begin{array}{l}0.10^{*} \\
(0.04)\end{array}$ & $\begin{array}{l}.095^{\star} \\
(2.24) \\
\end{array}$ \\
\hline D_EU & $\begin{array}{l}1.53^{*} \\
(0.13)\end{array}$ & $\begin{array}{c}\text { omitted } \\
\text { for collinearity }\end{array}$ & $\begin{array}{l}1.692^{*} \\
(2.40)\end{array}$ \\
\hline Constant & $\begin{array}{l}-5.23 \\
(0.63)\end{array}$ & $\begin{array}{l}-2.71 \\
(0.45)\end{array}$ & $\begin{array}{l}-4.128 \\
(-4.58)\end{array}$ \\
\hline $\mathrm{R} 2$ & 0.88 & 0.72 & 0.83 \\
\hline Wald chi2(6) & & & $\begin{array}{c}886.44 \\
(\mathrm{p} \text {-value }=0.000)\end{array}$ \\
\hline F test & $\begin{array}{r}\mathrm{F}(6,367)=1064.77 \\
(\mathrm{p} \text {-value }=0.000)\end{array}$ & $\begin{array}{l}\mathrm{F}(5,21)=222.36 \\
(\mathrm{p} \text {-value }=0.000)\end{array}$ & \\
\hline \multicolumn{2}{|l|}{ Number of obs. } & \multicolumn{2}{|c|}{374} \\
\hline \multicolumn{2}{|l|}{ Number of groups } & \multicolumn{2}{|c|}{22} \\
\hline
\end{tabular}




\begin{tabular}{|l|c|}
\hline BP Lagrangian multiplier test & $1900.88(\mathrm{p}$-value $=0.000)$ \\
\hline Hausman test $\dagger$ & $33.69(\mathrm{p}$-value $=0.000)$ \\
\hline
\end{tabular}

Standard errors in parenthesis; ${ }^{*}$ p-value $\leq 5 \%$; ${ }^{* *} \mathrm{p}$-value $>5 \%$ and $\leq 10 \%$; $\neq$ DPOP has been dropped in all three estimations, because it resulted not statistically significant at $90 \%$ C.I.; $\dagger$ Hausman test conducted on model estimates without robust s.e.

First of all, a very significant $(\mathrm{p}$-value $=0.0000)$ and negative relationship of -0.83 is observed between the dependent variable (AREABIO) and the YIELD. This result has the statistical meaning that an increase of $1 \%$ in the yield of the triticale would reduce the triticale land use by $0.83 \%$. Another very significant ( $p$-value $=0.0000$ ) and positive correlation of 0.87 is found between the dependent variable and that representing the per-capita quantity of the triticale (QTPOP). This would mean that an increase of $1 \%$ of the per-capita quantity of the triticale generates a rise of the triticale land use of $0.87 \%$. A further very significant ( $\mathrm{p}$-value $=0.01$ ) and positive relationship of 0.13 is observed between the dependent variable and the price of electricity for households (PELEC). This means that a growth of $1 \%$ in the considered type of electricity price would generate an increase of the triticale land use of $0.13 \%$. Still significant $(\mathrm{p}$-value $=0.09)$ and positive is the relationship - equal to 0.11 - between the triticale producer price index (PRICEX) and the dependent variable. This result would show that an increase of $1 \%$ in the triticale producer price index produces an increase of the triticale land use of $0.11 \%$. With regard to the two dummy variables that have been used in the model, a highly significant ( $\mathrm{p}$-value $=0.03$ ) and positive correlation of 0.10 between the dependent variable and that associated to the existence of incentive schemes for renewable energy production (D_FEEDIN) is observed.

\section{Considerations for policy implications}

The results achieved from the empirical investigation would prove that the triticale land use in the OECD area is affected - at a certain degree - by the variables that were considered in the model. Although this is true from a statistical point of view, doubts arise in terms of the economic validity of the estimated coefficients. This is particularly true for the case of the YIELD. The negative sign of its estimated coefficient would contrast the authors' predictions. One of the reasons to explain this unexpected result could be that an increase in the yield would rather cause land to be used to satisfy other needs (e.g. nutritional needs) rather than that of being used for bio-energy purposes.

Similar uncertainties also convey for the relatively small increases of the triticale land use as a result of variations in electricity and triticale producer prices. With regard to this, farmers would not seem to be willing to substantially increase the area devoted to the production of the triticale. A possible explanation for this could be identified in the fact that in the majority of European countries agricultural subsidies for cultivating bioenergy feedstock are the same as those paid for other crops. Without a more adequate incentive scheme, therefore, farmers would be discouraged to cultivate energy crops considering the still relatively low level of fuel prices (Lötjönen \& Laitinen, 2009). The imple- 
mentation of a proper incentive scheme is essential if the commitment of the European Union - undertaken in 2007 - is considered, which aims to increase the proportion of the production of renewable energy to $20 \%$ of the total energy consumption by the year 2020 (European Commission, 2009). It becomes evident how field crops particularly devoted to energy production and farmers - supported by adequate financial tools - can play an important role to reach the above-mentioned target. The provision of further governmental incentives would, therefore, be advisable to put farmers and - in more general terms - agricultural systems in the condition of giving their contribution in the above sense despite the current economic crises, which prevent governments from doing so. Unfortunately, many governments of the Euro-zone are currently taking a completely different direction and revising their support schemes in favour of the production of renewable energies. For example, Germany has recently cut its subsidies by $15 \%$ and further cuts may take place over the next few years. The UK has also reduced subsidies for renewable energy by $50 \%$, as did Italy. In Spain, some subsidies have been totally abandoned and the Czech Republic is also going in the same direction as their neighbouring countries, where substantial cut in subsidies are currently taking place (KPMG, 2012).

Of course, the creation of an incentive scheme aimed at generating favourable conditions for agricultural operators to produce biomass for energy production cannot be made without fitting it in the broader context of a land use policy based on the adoption of environmentally sustainable policies. With regard to this, it should not be left unconsidered that, through the Marrakesh Accords (UNFCCC, 2002), the United Nations Climate Change Secretariat has launched the rules to regulate on land use, while considering the environmental sustainability concept in terms of accountability of emission removals from forest and cropland management (Land Use Change and Forestry - LULUCF). Farmers can largely contribute to this policy initiative through the implementation of good practices aimed at securing $\mathrm{CO}_{2}$ emission reductions, sustainable land conversion practices to preserve productivity in agriculture soils. In the EU, 'the LULUCF accounting rules will help to strengthen the capacity of forests and agricultural soils to preserve and capture $\mathrm{CO}_{2}$ in a sustainable manner'

\section{Concluding remarks}

The present study is an early attempt at mainly analysing the interdependencies existing between a specific form of land use for biomass production (that is, for triticale production), agricultural and energy prices. After having highlighted some features, which make triticale suitable to satisfy nutritional and energy needs, the authors have pointed out some of its main production aspects. With regard to this, it has been observed how its market is continuously expanding. Some European countries (i.e., Poland, France and Germany) are the main producers at a global level and outside Europe there is evidence for the triticale used as a main feedstock for bio-refinery purposes.

Overall, through the use of the econometric technique of panel-data, the authors have observed the possible relationships between the triticale (considered in terms of and land use for its production) and a number of variables, such as the triticale yield, the 
price index for electricity, the producer price index for triticale, the triticale production (quantity in per capita terms) and two dummy variables. Among other evidences, the result of the empirical task suggests the existence of a positive relationship - although quantitatively very low - between the triticale land use and the variable associated to the triticale producer's price index. Another positive relationship - even in this case quantitatively very small - is observed between the triticale land use and the market price index of electricity. These two results, although very low from a quantitative point of view, match the authors' predictions. Such evidence would allow saying that farmers do not seem to be willing to substantially increase the production of the considered type of biomass unless an incentive scheme is provided.

\section{References}

1. De Lucia, C.; Datta, B. Socio-Economic, Environmental and Policy Perspectives of Second Generation Biodiesel. In: Luque, R. and Melero, J. A. (eds.). Advances in Biodiesel Preparation. Second Generation Processes and Technologies. Series in Energy: No. 39. Philadelphia: Woodhead Publishing, 2012.

2. De Lucia, C. Multiple Objectives Policies for Biofuels Production: Environmental, Socio-Economic and Regulatory Issues. In: Luque, R.; Campelo, J. M. and Clarke, J. (eds.). Handbook of Biofuels Production: Processes and Technologies. Series in Energy: No. 15. Cambridge, Woodhead Publishing, 2011.

3. European Commission. Commission Directive 2009/28/EC of the European Parliament and of the Council of 23 April 2009 on the Promotion of the Use of Energy from Renewable Sources and Amending and Subsequently Repealing Directives 2001/77/ EC and 2003/30/EC. Official Journal of the European Union. 2009, L 140: 1662.

4. FAO. Rome Declaration on Food Security and World Food Summit Plan of Action, World Food Summit. 13-17 November, Rome, Italy, 1996.

5. Fargione, J.; Hill, J.; Tilman, D.; Polasky, S.; Hawthorne, P. Land Clearing and the Biofuel Carbon Debt. Sciencexpress. 2008, 7.

6. Fedoroff, N.; Cohen, J. Plants and Populations: Is There Time? Proceedings of the National Academy of Sciences. USA, 1999, 96: 5903-5907.

7. Food and Agriculture Organization of the United Nations (FAO). The Market and Food Security Implications of the Development of Biofuel Production. In: FAO Committee on Commodity Problems. Sixty-seventh session, Rome, April 20-22, 2009.

8. Greene, W. Econometric Methods. 3rd Int. ed. Prentice Hall: Englewood Cliff, NJ, 1997.

9. Hoogwijk, M.M.; Faaij, A.; Van den Broek, R.; Berndes, G.; Gielen, D.; Turkenburg, W. Exploration of the Ranges of the Global Potential of Biomass for Energy. Biomass and Bioenergy. 2003, 25: 119-133.

10. International Energy Agency. World Energy Outlook. Paris, France, 2013.

11. International Energy Agency. World Energy Outlook. Paris, France, 2012.

12. International Energy Agency. Sustainable Production of Second Generation Biofuels. Potential and Perspectives in Major Economies and Developing Countries. Paris, France, 2010. 
13. International Energy Agency. World Energy Outlook. Paris, France, 2006.

14. Intergovernmental Panel of Climate Change (IPCC). Land-Use, Land-Use Change, and Forestry. Special Report of the Intergovernmental Panel on Climate Change. R. Watson et al. (eds.). UK: Cambridge University Press, 2000.15. Johnston, J.; Di Nardo, J. Econometric Methods. New York: McGraw-Hill, Inc., 1997.

16. Naylor, R.; Liska, A.J.; Burke, M.B.; Falcon, W.P.; Gaskell, J.C.; Rozelle, S.D.; Cassman, K.G. The Ripple Effect: Biofuels. Food Security, and the Environment, Environment. 2007, 49(9): 31-43.

17. OECD-FAO. Agricultural Outlook 2006-2015. OECD and FAO, Paris, France, 2006.

18. Righelato, R.; Spracklen, D.V. Carbon Mitigation by Biofuels or by Saving and Restoring Forests? Science. 2007, 317: 902.

19. Smeets, E.; Faaij, A.; Lewandowski, I.; Turkenburg, W. A Bottom-Up Assessment and Review of Global Bioenergy Potentials to 2050. Energy and Combustion Science. 2007, 33: 56-106.

20. VTT. Bioenergy Technology Review. Espoo, Finland, 2007.

21. Wooldridge, J. M. Econometric Analysis of Cross Section and Panel Data. 2nd ed. Cambridge, Massachusetts: MIT Press, 2010.

22. Yaffe, R. A Primer for Panel Data Analysis. New York: New York University, 2003.

\section{Electronic Sources:}

1. Barnett, R. D.; Blount, A. R.; Pfahler, P. L.; Johnson, J. W.; Buntin, G. D.; Cunfer, B. M. Rye and Triticale Breeding in the South. University of Florida, IFAS Extention. Working paper SS-AGR-42. 2002 [interactive]. [accessed on 27-09-2013]. <http:// edis.ifas.ufl.edu/pdffiles/AG/AG14700.pdf>.

2. Department for Environment, Food and Rural Affair (DEFRA). The Impact of Biofuels on Commodity Prices. 2008 [interactive]. [accessed on 28-09-2013]. <rsb.org/pdfs/ documents_and_resources/Food-versus-fuel-DEFRA-April08.pdf >.

3. Ernst \& Young. Biofuels and Indirect Land Use Change. The Case of Mitigation. 2011 [interactive]. [accessed on 27-09-2013]. <www.endseurope.com/docs/111005a.pdf >.

4. Food and Agriculture Organization of the United Nations. WTO Rules for Agriculture Compatible with Development. 2008 [interactive]. [accessed on 31-05-2013]. <http:// www.fao.org >.

5. International Energy Agency. Bioenergy, Land Use and Climate Change Mitigation. 2011 [interactive]. [accessed on 26-09-2013]. <www.ieabioenergy.com/DownLoad. aspx?DocId $=6775>$.

6. KPMG. Taxes and Incentives for Renewable Energy. 2012 [interactive]. [accessed on 27-09-2013]. <http://www.kpmg.com/Global/en/IssuesAndInsights/ArticlesPublications/Documents/taxes-incentives-renewable-energy-2012.pdf $>$.

7. Lötjönen, T.; Laitinen, T. Energy from Field Energy Crops - A Handbook for Energy Producers. Jyväskylä Innovation Oy, Jyväskylä, Finland, 2009 [interactive]. [accessed on 24-04-2013]. <www.aebiom.org/wp-content/uploads/file/Publications/ Handbook for energy producers.pdf $>$. 
8. United Nations Framework Convention on Climate Change (UNFCCC). Report of the Conference of Parties on Its Seventh Session held at Marrakesh from 29 October to 10 November 2001 - Addendum. Part Two. Action taken by the Conference of the Parties, vol. 1. 2002 [interactive]. [accessed on 24-04-2013]. <http://unfccc.int/ resource/docs $/$ cop7/13a01.pdf\#page $=54>$.

\section{ŽEMĖS ŪKIO IR ENERGIJOS KAINŲ İTAKA BIOMASĖS GAMYBAI: KVIETRUGIŲ ATVEJIS EBVO REGIONE}

Santrauka. Taikant ekonometrinius metodus ir naudojant panelinius duomenis tyrinejjami ryšiai tarp žemès ūkio ir energijos kainų bei žemés panaudojimo kvietrugiams, kurie šiuo metu laikomi vienais svarbiausių biomasès augalų. Šio tyrimo tikslas yra nustatyti žemės naudojimo pasekmes, susijusias su politikos priemonèmis, skatinančiomis atsinaujinančių energijos išteklių naudojimą. Analizei pasirinkti 22 EBVO šalių 17 metų - nuo 1995 iki 2011 m. - duomenys. Analizès rezultatai parodè, kad apskaičiuota žemès naudojimo kvietrugių auginimui funkcija visų pirma priklauso nuo derliaus pokyčių bei gamintojo ir energijos kainų. Gautos politikos rekomendacijos pabrěžia, kad žemdirbiai nèra linkę plèsti kvietrugiais apsodinamų žemės plotų be specialių ekonominių biomasès augalų auginimo iniciatyvų.

Caterina de LUCIA has a MSc and a PhD in Environmental Economics and Environmental Management from the University of York (UK) and works as an assistant professor in environmental economics and economic policy at the Department of Economics of the University of Foggia (Italy), where she is also involved in teaching activities. She has previously worked at the Universities of Sheffield (UK), York (UK) and Duke (USA). She is also a member of the Laboratory of Economics, Environment and Regional Sciences (LEEReS). Among her main research interests, the policy regulatory aspects associated to issues, such as climate change, deforestation, bio-fuels and sustainable development, have a central role.

Caterina de LUCIA - Aplinkosaugos ekonomikos ir aplinkos valdymo mokslų daktarè, Jorko universitetas Jungtinė Karalystė. Aplinkos ekonomikos ir ekonominés politikos katedros docenté, Foggia ekonomikos universitetas, Italija. Mokslinių interesų sritis: politikos reguliavimo klausimai, klimato kaita, miškų naikinimas, biodegalų gamyba, tvari plètra.

Francesco CONTO is full professor of Agricultural Economics at the Economics Department of the University of Foggia (Italy). The issues of rural development, multi-functionality in agriculture, innovation and competitiveness in the agro-food system, health implications of innovation in the food sector are those, where he focuses his major research and teaching interests. Apart from his expertise in various European projects, he is the leader of various transnational cooperation activities.

Francesco CONTO - Ekonomikos katedros profesorius, Foggia universitetas, Italija. Mokslinių interesų sritis: kaimo plètra, multifunkcija žemès ūkyje, inovacijos ir konkurencingumas žemès ūkio ir maisto produktų sistemoje, inovacijų poveikis sveiko maisto sektoriui.

Pasquale PAZIENZA has a MSc in Environmental Economics from the University of York (UK) and a PhD in Policies for Territorial Sustainable Development from the University of Bari 
(Italy). At present, he is a researcher in economic policy in the Department of Economics of the University of Foggia (Italy), where he teaches various economic courses. His research interests focus on European policies and economic local development. He is a member of various European and international research teams. In addition to his academic commitments, he has previously worked as a consultant for various local socio-economic development plans in southern Italy and, more recently, he has been called to cover governmental positions in local institutions.

Pasquale PAZIENZA - Tvarios teritorinès politikos plètros doktorantas, Bario universitetas, Italija. Ekonominès politikos tyrimai ekonomikos katedroje Foggia universitete, Italija. Mokslinių interesų sritis: Europos politikos kryptys, ekonomikos pletra.

Vincenzo VECCHIONE is Associate Professor of Economic Policy at the Department of Economics of the University of Foggia. He is also the scientific director of the Laboratory of Economics, Environment and Regional Sciences (LEEReS). His main research interests focus on economic development, fiscal and monetary policies.

Vincenzo VECCHIONE - Ekonomikos katedros docentas, mokslų daktaras, Foggia universitetas. Aplinkos ir regionų ekonomikos mokslinès laboratorijas (LEEReS) diretorius. Mokslinių interesų sritis: ekonominè plètra, fiskalinè ir pinigų politika. 